\title{
Demotic Lists of Personal Names
}

Soheir Mohamed Wahid El-Din

\section{Abstract:}

The study concerns four lists of personal names from Gebelin in the Egyptian Museum at Cairo. They are registered in the inventory books of the Museum in 1955, and Preserved on the third floor P.23 East. Their number is "Inv. No./TR. 18953/25-1-55/4". All lists are Ptolemaic in date, one of them has a heading (No.1), and two others are Partly broken (Nos.1,4). The dot as a partition indication is also used (No. 4).

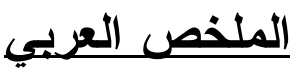

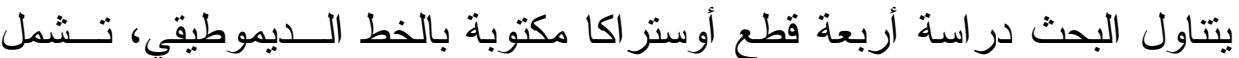

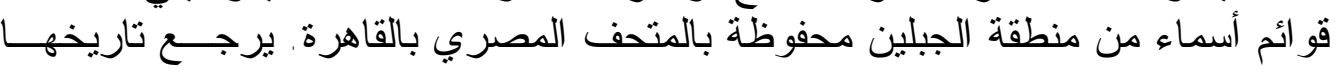
اللعصر البطلمي. تحتوي كل القو ائم علي أسماء شائعة الاستخدام بمنطقة الجبلين.

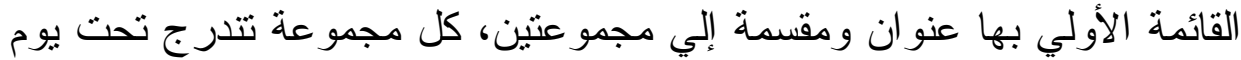

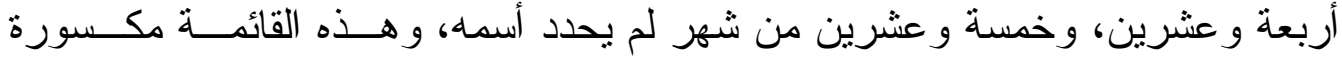

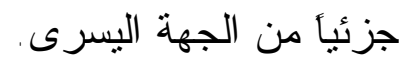
القائمة الثانية نصها مكتمل وبها ثمانية أسماء.

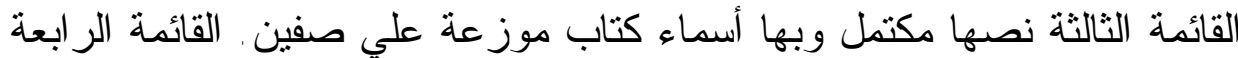

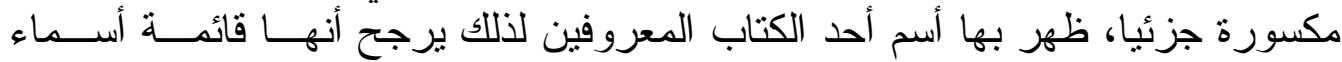

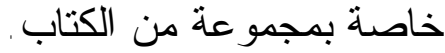

•Mansoura University 
The study concerns four lists of personal names from Gebelin in the Egyptian Museum at Cairo. They are registered in the inventory books of the Museum in 1955, and Preserved on the third floor P.23 East. Their number is "Inv. No./TR. 18953/25-1-55/4". The prefixed inventory letters before the number "Inv.No./TR." refer to the inventory number of the inventory book in the museum (Inv.No.18953)to (/), the train register number (TR.), which represents day 25/month (January)/year 1955, Train (4).

All lists are Ptolemaic in date, one of them has a heading (No.1), and two others are Partly broken (Nos.1,4). The dot as a partition indication is also used (No. 4).

1- Museum Number : Inv. No./TR. 18953/25-1-55/4.

Dimensions : Max. height $14 \mathrm{~cm}$; max. width $9 \mathrm{~cm}$;

Thickness $0.5 \mathrm{~cm}$.

Color

: Yellowish-Red.

Provenience

: Gebelin.

Date

: Ptolemaic

The shard is partly broken at the left side from line seven to its end.

\section{Transliteration:}

1- sw 24 pA--.--- i.ir ir-wS

2- PAmr-iH sAnAnxT=f sA-.....

3- PASr-I s.t sAPAtj-irj-Hms-nfr

4- @r-wDA=f pAamr

5- Pa - tw sAPa -tw-apA

6- PASr-inp sAPASr-iaH

7- PASr-mnx sAGI[A]

8- PAtj-Wsir sAP a -tw

9- sW $25 \mathrm{PA}$

10- P a -M n SAPA[

11- PASr-[ -.-.-.- 


\section{Translation:}

1- Day 24 pA---.-- i.ir ir-wS

2- $P A m r-i H$ son of $n A n x T=f s A-\ldots$

3- PASr-I s.t son of PAtj-irj-Hms-nfr

4- @r-wDA=f pAamr

5- $\mathrm{Pa}$-tw son of $\mathrm{Pa}-\mathrm{tw}-\mathrm{apA}$

6- PASr-inp son of PASr-iaH

7- $P A S r-m n x$ son of $G \mid[A]$

8- PAtj-Wsir son of $\mathrm{Pa}$-tw

9- Day 25 PA -.-.-.--

10-Pa - Mn son of PA[ -....-.

11-PASr-[ -...-.

\section{Comment:}

L.1- The reading of the two signs

as rmTqs "Embalmer" is possible. I cannot find an instance which can confirm this

reading. O.Leiden (No.383, col. 1,2) had discussed the same second sign $\boldsymbol{s}$ as a determinative of the word qs "Embalmer". ${ }^{(1)}$

L.2- The reading of the third name is not certain, it could be @r, @r wDA, or @r - nxT?

L.4- PA ${ }^{c} \mathrm{mr}^{(2)}$ (craft or craftsman) I do not Know if it is a title or a job of @r -wDA=f,

L.5- There is no a similar combination of the second proper name PA- tw-apA

L.7- The father's name is partly broken, the missing part has the last element and the determinative.

L.9- This line must has a heading of the second group of the names.

The days 42 and 25 at this list refer to the daily register administrative.

${ }^{1}$-Nur El-Din, M.A.A., The Demotic Ostraca in the National Museum of Antiquities at Ledien, E.J. Brill, Leiden, 1974, 300-2.

${ }^{2}$-Erichsen, W., Demotisches Glossar, Ejnar Munksgaard, Kopenhagen, 1954, 61. 
2- Museum Number : Inv. No./TR. 18953/25-1-55/4.

Dimensions : Max. height $11 \mathrm{~cm}$.; max. width $6.5 \mathrm{~cm}$;

Thickness $0.7 \mathrm{~cm}$.
Color
: Red.
Provenience
: Gebelin
Date
: Ptolemaic

The text is completed, it has no heading.

\section{Transliteration}

1- PAwr-5

2- PASr-inp

3- PAlw

4- Pa -tAwj sAPASr-inp

5- PAhb SAPa -tw

6- PAtj-Is.t sAPAtj-\%k

7- PAmr-iH sAPAXrT

8- PASr-Is.t sAPa -tAwj

\section{Translation}

1- PAwr-5

2- PASr-inp

3- PAIW

4- Pa -tAwj son of PASr-inp

5- PAhb son of $\mathrm{Pa}$-tw

6- PAtj-Is.t son of PAtj-\%ok

7- PAmr-iH son of PAXrT

8- PASr-Is.t son of $\mathrm{Pa}-\mathrm{tAwj}$

\section{Comment:}

L.1-2- The names of the two lines appear as father and son in O.Zürich No.33.3. ${ }^{(3)}$

PA-SA- inp SA PA- wr - 5. But it is not certain, if they are the same persons or not?

3 -Wångstedt, S.V., Die demotischen Ostraka der Universität zu Zürich, Almquist \& Wikselle Boktryckeri AB, Uppsala, 1965, 40. 
L.2- The second and the third elements of inp are very faint

L.7- The first proper name is washed out and written again.

L.8- This name is known from O.Tepleide (No. 172.2, 21). ${ }^{\left({ }_{4}\right)}$

3- Museum Number : Inv. No./TR. 18953/25-1-55/4.

Dimensions : Max. height $11 \mathrm{~cm}$; max. width $3 \mathrm{~cm}$.;

Thickness $0.6 \mathrm{~cm}$.

Color

: Red.

Provenience

: Gebelin

Date

: Ptolemaic

The surface of the shard is scratched and palimpsest.

\section{Transliteration}

\section{Col.1}

1- $n A n x T=f s A \& H w t j$

2- nXT-Mn

3- PAwr-iAbt

\section{Col.11}

1- Pa -tAs.t-aAt

2- Grwr

3- PASr-Hr-(pA)-XrT

\section{Translation}

\section{Col.1}

1- $n A n x T=f$ son of $\& H w t j$

2- nXT-Mn

3- PAwr-iAbt

${ }^{4}$-Kaplony-Heckel, U., Die demotischen Tempeleide, otto Harrassowitz, Wiesbaden, 1963, 2Vols. (Ägyptologische Abhandlungenb), 285. 


\section{Col.11}

1- Pa -tAs.t-aAt

2- Grwr

3- PASr-Hr-(pA)-XrT

\section{Comment:}

\section{Col. I}

L.1- Notice, the sign SA (son of ) between the two names is very faint.

L.3- PAwr-iAbt is a scribe. He is known from other published texts. ${ }^{(5)}$

\section{Col. II}

L.1- Pa -tAs.t-aAt is a known scribe ${ }^{(6)}$. He signed many receipts which are dated to the late Ptolemaic period.

L.2- There is no available instance for this name, but it is mentioned in Demotisches Namenbuch ${ }^{(7)}$.

The text deals with a list of proper names who are scribes. Two of them are known from other published texts.

4- Museum Number : Inv. No./TR. 18953/25-1-55/4.

Dimensions : Max. height $8 \mathrm{~cm}$; max. width $7.5 \mathrm{~cm}$.; Thickness $1 \mathrm{~cm}$.

Color : Red.

Provenience : Gebelin

Date : Ptolemaic

${ }^{5}$-Mattha, G., Demotic Ostraca from the Collections at Oxford, Paris, Berlin, Vinna and

Cairo, Le Caire, 1945, (Publications de la societe fouad I de papyrologie Textes et Decuments VI), 173, No. 231.4.; Wångstedt, S.V., "Demotische Ostraka aus der sammlung des Ashmolean Museums in Oxford, OrSu 14-15, 1965-1966, 18, No. 2.; Kaplony-Heckel, U., Pathyris

Demotische Kurz-Texte in Cairo, Enchoria 19/20, 1992/1993, 57, No. 7.

${ }^{6}$-Wångstedt, S.V., OrSu 14-15., 23-24, 28-29, 33,41, Nos. 14, 19, 20, 26, 36.; Kaplony-Heckel, U., Enchoria 19/20., 56, 77-78, Nos. 4-5, 28.

${ }^{7}$-Lüddeckens, E. \& others, Demotishes Namenbuch, DR. Ludwig Reichert Verlag,

Wiesbaden, 1996, Vol. 1, Part 14, 1029, 1031. 
The shard is partly broken at the top and the right sides.

\section{Transliteration}

1 - $[-----[\%]$ bk

2- [-----]PASr-Is.t

3- [P a ]-tAs.t-aAt sAP a -\%k

4- Pa -tw sAPa - tAwj

\&Hwtj-i.ir-tj=s sAG IA

5- Pa -tw sAPa -nAnb-bXn

\section{Translation}

1- [------]-[\%]bk

2- [--.-.-.]PASr-Is.t

3- [Pa ]-tAs.t-2At son of $\mathrm{Pa}-\% \mathrm{bk}$

4- $\mathrm{Pa}$ - tw son of $\mathrm{Pa}-\mathrm{tAwj}$

$\& H w t j-i . i r-t j=s$ son of $G I A$

5- $P a-t w$ son of $P a-n A n b-b X n$

\section{Comment:}

L.1- The remaining part of the proper name could be recognized as $\mathrm{Pa}-\% \mathrm{bk}$.

L.2- The first proper name must be found at the missing part.

L.3- The first element of the proper name $\mathrm{Pa}$ is missing, and the second element tA is partly broken. .

L.4- This line has two proper names, a dot is used as partition indication to separate between them.

- \&Hwtj-i.ir-tj=s son of GIA is a scribe. He is known from other published texts ${ }^{(8)}$.

- The father's name GIA appears in the first list (No. 1,7) it is not known, if he is the same person or not.

In this list the text contains a name of a scribe, may be the rest names are scribes too.

8 -Wångstedt, S.V., OrSu 14-15, 1965-1966, 45.; Kaplony-Heckely, U., Enchoria 19/20, 1992/1993, 54-55, Nos. 2-3. 
دراسات في آثار الوطن العربي 11

PI.
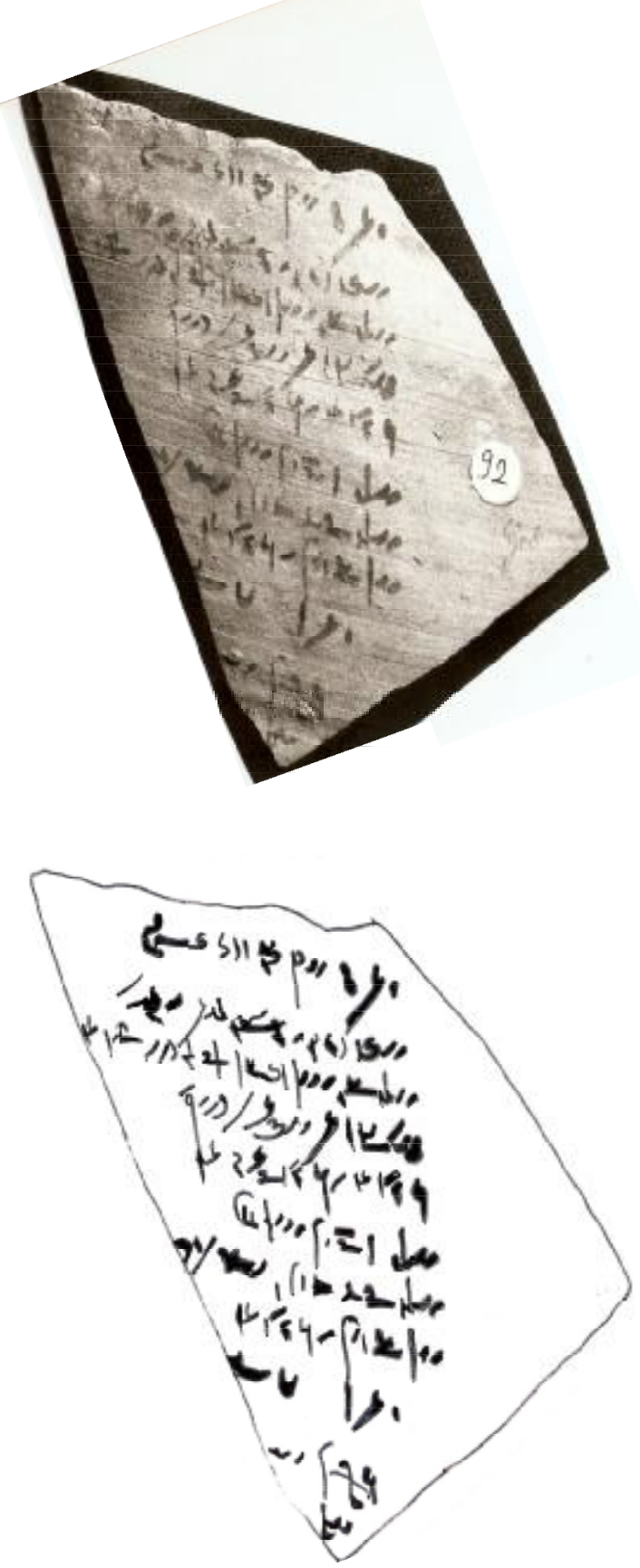

Inv. No.

/TR.18953/25-1-55/4

$-8-$

PDF created with pdfFactory Pro trial version www.pdffactory.com 
دراسات في آثار الوطن العربي 1

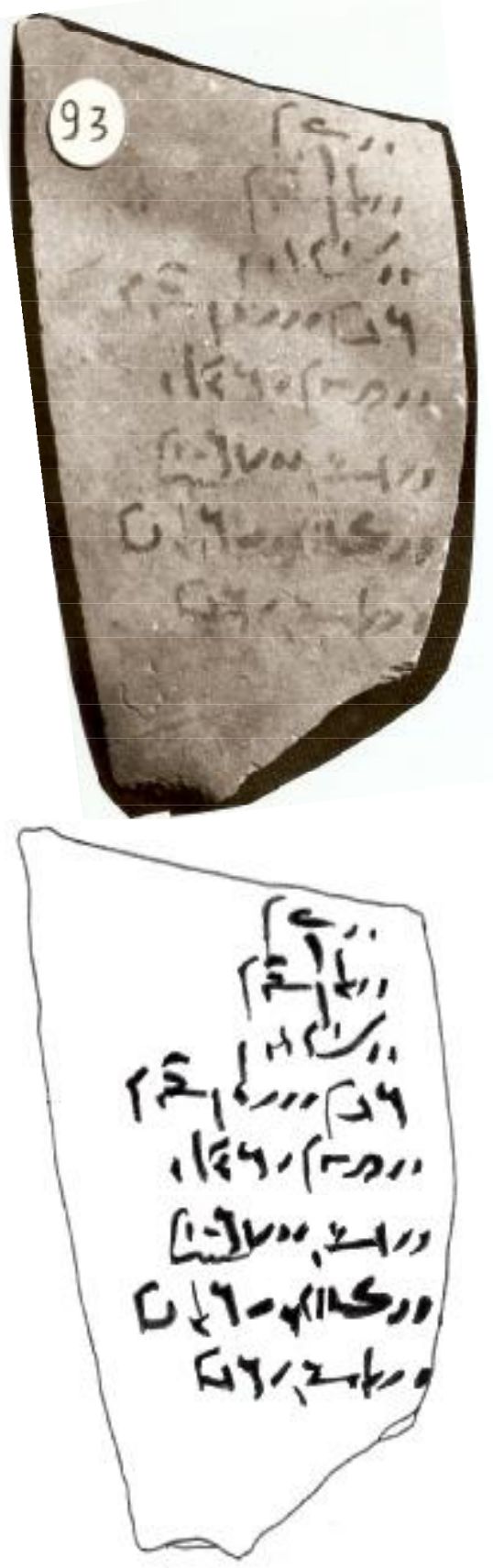

Pl.2

\section{Inv. No. /TR.18953/25- \\ 1-55/4}


دراسات في آثار الوطن العربي 11

PI.3
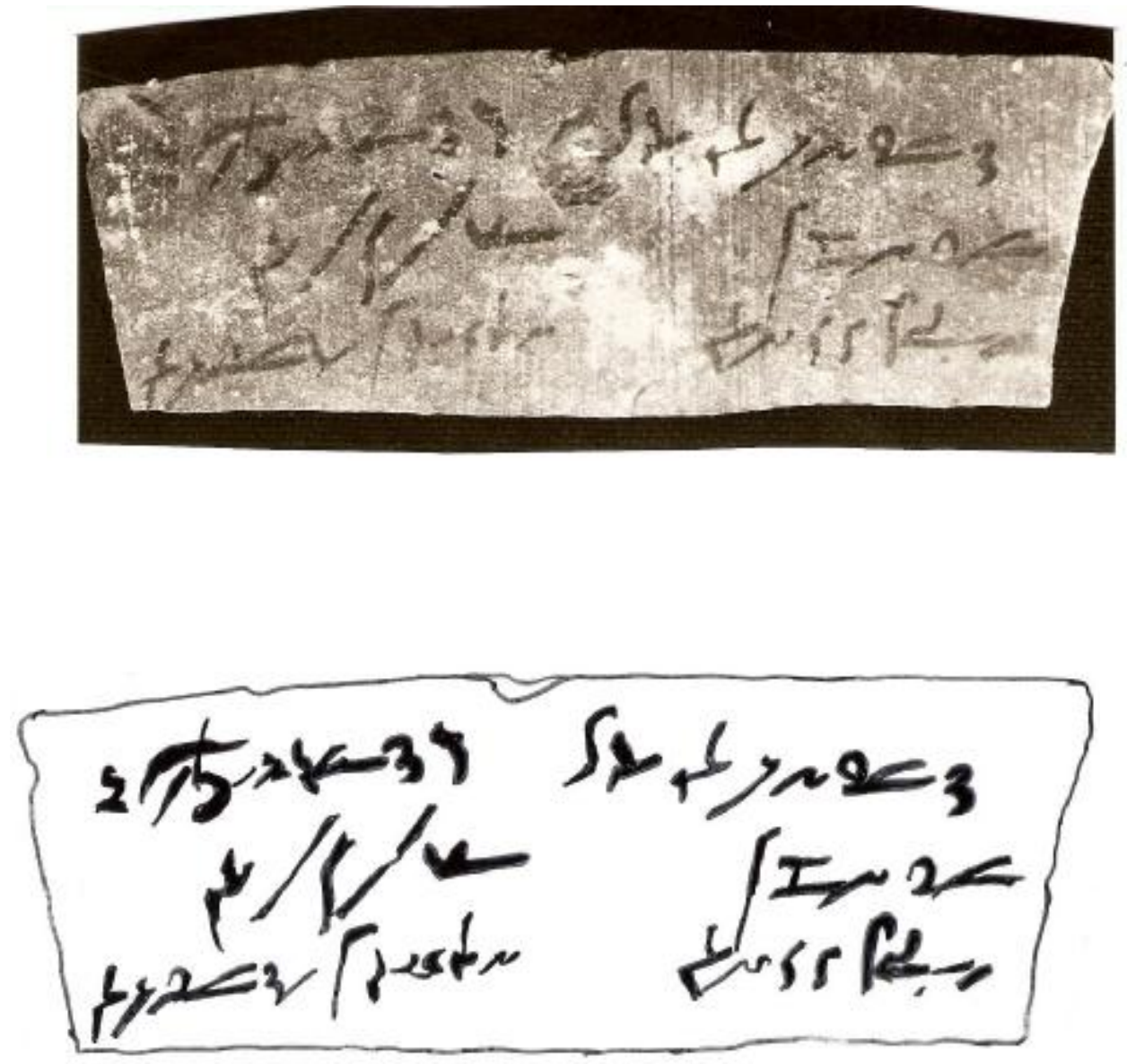

Inv. No. /TR.18953/25-

$1-55 / 4$ 
دراسات في آثار الوطن العربي 11

Pl.4
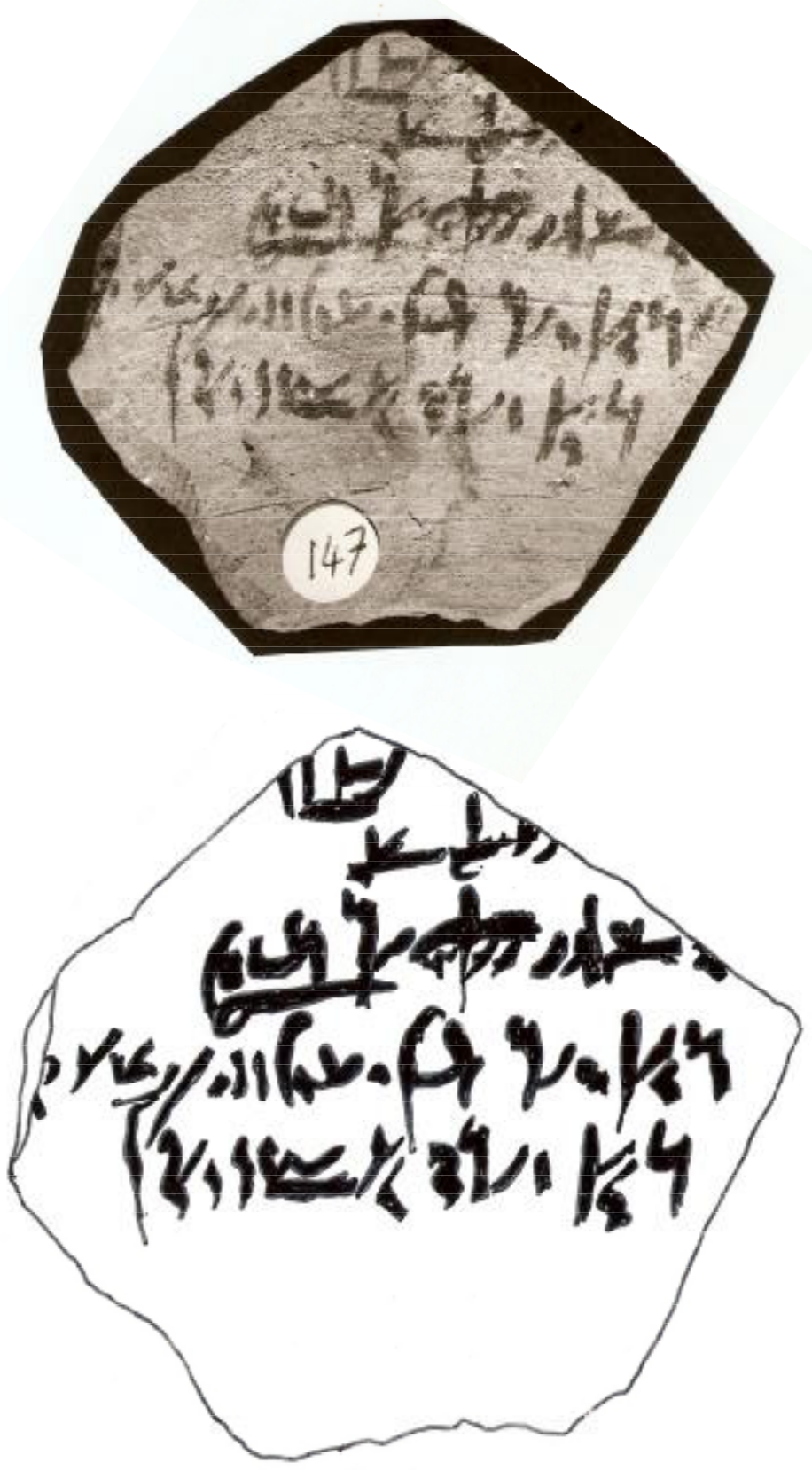

Inv. No. /TR.18953/25-

1-55/4 